TRABAJO Y TRABAJADORES:

RED LATINOAMERICANA

\title{
Conference Report: "Empire, Sovereignty, and Labor in the Age of Global Abolition"
}

\author{
SimEON SimEONOV \\ Brown University \\ simeon_simeonov@brown.edu
}

Hosted by the McNeil Center for Early American Studies and the University of Pennsylvania's School of Arts and Sciences, the conference "Empire, Sovereignty, and Labor in the Age of Global Abolition" (February 25-26, 2021) gathered an array of scholars interested in reconceptualizing the history of abolition as a global phenomenon. From the appropriation of customary traditions in British India to the illicit transatlantic slave trade and the continuation of slavery under free-womb regimes in South America, the participants examined the myriad ways in which slavery endured-and expanded - over the nineteenth century, a period traditionally conceived as the heyday of the industrial factory and the proliferation of wage labor across the globe. Embedded within local structures of governance and global networks of commerce, slavery proved particularly resilient to the efforts of a growing abolitionist challenge mounted by free and enslaved people of color, as well as such disparate groups as abolitionist activists, free-labor industrialists, and imperial and national officials. If the multinational and multifaceted experiences examined in the course of the conference suggest any point for a larger generalization, it is that of recognizing slavery as a global institution remarkably impervious to abolition yet also surprisingly adaptable to change; an institution that invariably left its lasting impact on the post-emancipation regimes that followed in its wake.

The history of abolition emerging from these conversations is different from the more familiar history of abolitionism, a history focused on the efforts of abolitionist organizations to galvanize support for the abolition of slavery. Though certainly important, the figures of William Wilberforce, Thomas Clarkson, William Lloyd Garrison, Frederick Douglass, Harriet Tubman, 
Harriet Beecher Stowe, Joaquim Nabuco, André Rebouças, Julio Vizcarrondo, and a host of others, give way to a new cast of figures, men and women of African and Indigenous descent as well as their white allies, who challenged the institution of slavery through individual and collective acts of resistance. In line with current efforts in academic scholarship, the conference participants insisted on the importance of excavating and reintegrating marginalized voices in the making of the global Age of Abolition.

A focus on marginalized individuals as agents of abolition entails challenging traditional conceptual frameworks. Such an approach may take the form of "geopolitical literacy," Isadora Mota's conceptual tool for rethinking the history of Brazilian abolitionism by placing black Brazilians in the midnineteenth century at the center of the struggle for the eradication of slavery in one of the western hemisphere's longest-lasting slaveholding societies. By virtue of their engagement with print materials during the U.S. Civil War, Mota argues, free and enslaved Brazilians of color disseminated ideas of liberation decades before the first Brazilian abolitionists began placing abolition on the imperial agenda. In a similar vein, Ndubueze L. Mbah shows the dexterity with which Liberated Africans along the Sierra Leone coast navigated a complex system of palm oil profits, freedom papers, and missionary activities to not only emancipate themselves but also extend the rights they had come to enjoy to other Africans in the immediate proximity of slaving operations. Their constructions of independence and autonomy eluded British recognition, but, as Caree Banton's work on Liberia demonstrates, Africans and African-descended migrants in these new spaces of black emancipation on the West African coast used material artefacts to refashion their post-emancipation identities by "convey[ing] values of postabolition productive labor." Caitlin Fitz's exploration of Emiliano Mundurucu, a cosmopolitan Brazilian émigré who toured a variety of nineteenth-century revolutionary battlegrounds, and Scott Heerman's exploration of Henry Francis Shirley and John Lytle, captive Africans in Spanish Cuba, foreground the importance of individual struggles of people of color in a historical period suffused with the tension between hemispheric abolition and the contested emergence of black citizenship.

The history of abolition also focuses our attention on another group of people usually omitted from histories of abolitionism, middling imperial agents and local bureaucrats operating in the elusive zone between state policy and peripheral exigency. Relying on state salaries or jockeying for administrative prestige, these white male officials navigated the uneasy transition from slavery to freedom, oftentimes assuming strategically ambivalent attitudes toward abolition in places like Martinique, Guadeloupe, or French Guyana (Joseph la Hausse de Lalouvière), British Guiana (Nathaniel Millett), and 
Haiti (Simeon Simeonov). The boundary between slavery and freedom mattered less to these imperial officials than the "pacification" of their jurisdictions or the accumulation of capital and prestige, and no moral or economic arguments seemed to hold sway over them as they exploited the disparities in state communications to position themselves as the arbiters of imperial reconstruction. Oftentimes, the interactions between these middling officials and Indigenous or African-descended people belied the abolitionist designs of national or imperial centers, suggesting lines of collaboration that prioritized local needs over central directives.

Emerging from these reevaluations of marginalized agency and imperial administration is the necessity for a critical reappraisal of the conceptual framework governing historical interpretations of global abolition. In a particularly impactful intervention, Keila Grinberg pointed to the concept of gradual emancipation, the widespread nineteenth-century notion of introducing a set of transitional institutions preparing the enslaved for the eventual enjoyment of freedom, as an inherently problematic category in need of further conceptual work. In Grinberg's analysis, gradual emancipation's implicit orientation toward freedom belied the convoluted trajectories of global abolition while also obscuring proslavery political investments. Grinberg's observation is particularly apposite in a literature which has devoted much greater attention to the process of gradual emancipation in the British Empire than in the "second-slavery" regimes in Spanish and Portuguese America.

As papers by Bianca Dang, Joseph la Hausse de Lalouvière, and Simeon Simeonov insisted, the category of immediate emancipation is in no less need of historicization than that of gradual emancipation. The literature on immediatism has traditionally emphasized the Haitian Revolution of 17911804 as the single example of a slave insurgency leading to the immediate abolition of slavery and the establishment of a free, staunchly antislavery, state. Previously disregarded as "exceptional" in a global comparative perspective, Haiti has attracted much recent attention from Atlantic historians, oftentimes serving as the paradigm against which other slaveholding societies are measured. Certainly, no other revolutionary regime advanced the cause of irreversible, immediate emancipation as powerfully as Haiti after 1793. And yet, by 1801 , the carriers of the same republican heritage which had brought about the eradication of slavery in Haiti reintroduced human bondage in nearby Martinique, Guadeloupe, and French Guyana; indeed, Napoleonic officials were likely to do the same in Haiti following the Leclerc expedition of 1802. Equally important, the postemancipation labor regulations in Haiti, notably Jean-Pierre Boyer's Code Rural of 1826, contained numerous limitations on Haitians' ability to refashion themselves as a free and independent people. 
How can we account for this peculiar development? It is instructive to follow de Lalouvière's dictum, which points out that pre-revolutionary systems of surveillance and policing coexisted with emancipatory practices in the French Antilles, enabling some post-emancipatory regimes to re-institute slavery without major empire-wide disturbances. In addition, a greater attention to the decades following Haitian independence suggests that Haiti's (and Haitians') path to freedom was no less convoluted or impactful after the revolution than during its course. Haitian abolitionists played an important role in the internationalization of immediate abolitionism and the global struggle for black equality (Dang), and the Haitian experience informed British plans for abolition, even if not in the ways intended by Haitian officials (Simeonov). These contributions suggest the necessity for inserting Haiti more carefully into the history of global abolition, considering the postemancipatory decades as integral to both understanding the impact and legacy of the revolutionary struggle, and examining the interactions between Haiti and the wider world - especially the Caribbean and Spanish Americain a measured way which accounts for local specificities.

The convoluted trajectory of gradual and immediate emancipation shows that abolition was a question of policy as much as a matter of personal persuasion. As Roquinaldo Ferreira observed, the modalities of abolishing slavery became a matter of constant negotiation and contestation between the enslaved and the agents of their oppression. Surprisingly, we know a lot more about how these negotiations proceeded in the British West Indies, the United States, Brazil, and the French Antilles than across the largest imperial domain in the western hemisphere, Spanish America. Given the convoluted and under-researched process of gradual emancipation throughout much of this region, the work of Latin American scholars is particularly illuminating. Filling this gap in historical scholarship, Marcela Echeverri, Yesenia Barragan, and Alice Baumgartner insisted on integrating the Spanish Main in histories of Atlantic abolition. Doing so will enable scholars to reconsider extant narratives of Latin America's hemispheric positionality vis-à-vis the United States (Baumgartner), think more expansively about the space of slavery and abolition at the level of interstate affairs (Echeverri), and emphasize the roles of actors usually omitted from narratives structured around the more familiar Anglo-North American experiences (Barragan).

Informed by the region's myriad antislavery measures from the $1810 \mathrm{~s}$ to the 1850s, a focus on Spanish America challenges explanations of abolitionism by suggesting new avenues for scholarship on the pervasive yet poorly understood slew of manumission juntas as well as the abundance of municipal, state, and national laws and regulations, none more conspicuous than the socalled "free womb" stipulations at the heart of Barragan's research. In the 
perhaps most striking instantiation of Grinberg's admonition, Barragan shows how the category of gradual emancipation worked to hide a brutal, expansive, and lucrative commerce in free-womb children across Gran Colombia's province of Chocó. Opening new scholarly vistas, Barragan's research bears important implications beyond the case of Spanish America, suggesting questions for further research. Why did only a few transactions at Quibdó's free-womb market explicitly refer to children of enslaved mothers as "property"? Why was the concept of "puberty" that determined the legal boundaries between different conditions of slavery so prevalent? Was this reflective of a shifting sensibility of the slave as a "perpetual" child, a middling passage of autonomy in a period of uncertain Latin American sovereignty? Or was the idea of "puberty" metonymic of the inclination of state-builders toward the new republican project? Providing answers to these questions might enable Latin American historians to account for the specificity of slavery's role in the nation-building projects - away from less productive discussions of its "centrality" or "marginality," which tend to obscure the significance of slavery as a discrete force in Latin American state formation.

Baumgartner's and Barragan's work also suggests a reconsideration of how proslavery advocates mobilized their resources in new regional and transnational coalitions. Precisely because slaveholders could claim that slavery was a mere form of naturally unequal relationships, and because they could sustain the fiction that enslaved people might aspire to achieve greater autonomy, they could claim that slavery was an adaptive, progressive institution, an argument attuned to popular gradualist ideas of apprenticeship as a "civilizing institution.” As the Americas were undergoing a host of revolutionary changes, slavery could not have survived if its advocates did not take these developments into account; even if they adopted a hostile attitude toward abolition, they had to find new ways of legitimizing their opinions. Comprehending these changing faces of slavery in the Age of Abolition is crucial to finding a link between the experiences of enslaved people on the sugar, coffee, and cotton plantations of "second-slavery" regimes and the various forms of post-emancipation exploitation which were variously described as slavery in all but name. Recognizing that these regimes and related labor systems operated in a spectrum of possibilities is tantamount to recognizing that the changing faces of slavery also connected - and connect — the past and the present.

Realizing that slavery took on a variety of forms in the course of gradual emancipation does not detract from the work of scholars who have emphasized the trait of inheritability, partus sequitur ventrem, as one of the most pervasive and traumatizing aspects of slavery as a labor-reproductive institution. In fact, showing the various ways in which slavery operated in an 
Age of Abolition - as a form of indentured servitude, debt peonage, penal labor, child labor, corvee labor, serfdom, etc.-opens new discussions about the regional varieties of this institution while also demonstrating its incredible fluidity as well as its deep embeddedness in the modern imaginary. "Indeed," writes de Lalouvière on the complex reality of revolutionary abolition, "legal distinctions of free and slave status often obscured the underlying social realities of dependency and domination that were neither reducible to slavery nor entirely separable from it."

The careful works of Padraic Scanlan, Roberto Saba, and Kellen Heniford further reinforce this observation, as all three show how important slavery was to constructing modern ideas of free labor in both its concrete economic manifestation and its wider political/ideological framework. Indeed, from these three mutually reinforcing interventions we can construe a similar argument about the importance of slave emancipation as a catalyst of capitalism. In Heniford's analysis, this entailed the creation of the "free state" as an operative political category distinct from a slave state or a state "with" slavery. To be functional, this construct required tangible material results, and abolitionists could point to the rising profits of sugar mills and coffee plantations after emancipation as powerful evidence of Smithian arguments about slavery's economic inefficiency (Saba). Pointing to the relative marginality of slave emancipation in the work of the classical liberal theorists of the period (Adam Smith, David Ricardo, Thomas Malthus, and John Stuart Mill), Scanlan suggests the utility of differentiating between political economists and antislavery advocates writ large, a useful insight in trying to chart the relationship between slavery, abolition, and capitalism. These scholars' research exposes the dichotomous formulation of slavery at the diametrical opposite of free labor as the product of abolitionists' intense ideological work in a rapidly expanding and politically charged public sphere. More fundamentally, a reckoning with slavery as one of multiple modes of the forceful extraction of labor is extremely generative to discussions about the relationship between slavery and capitalism.

Neither the project of abolition nor the rise of second slavery, it bears emphasizing, were Atlantic phenomena. Instead, both by virtue of the imperial networks in which they unfolded, and the nature of the economic and political debates they informed, these developments occurred on a global scale, as evident in Catherine Peters' and Mishal Khan's submissions. Examining the first importation of Chinese men from British India to a Caribbean colony, the newly acquired island of Trinidad in 1806, Peters argues that the Chinese laborers acted as a "barrier race" to the heightening of tensions between white settlers and a majority of African-descended slaves. In the case of British India examined by Khan, British imperial authorities in the mid-nineteenth-century abstracted forms of labor coercion 
into a rationale for everyday governance ("local custom"), thereby turning the contract, an equally abstracted form of coercion, into the sole marker of global modernity. In this way, the capitalistic elites who negotiated imperial labor regimes construed the emergence of coolie labor not as the continuation of slavery but as a natural consequence of the interplay between market forces and traditional relations. Abolition, in Khan's interpretation, was (and is?) being held hostage by the arrested modernity of the labor contract.

What emerges from all these contributions is a set of methodological considerations that might enable scholars to weave together disparate approaches into what Kathleen Brown's concluding remarks summarized as "dynamic global vectors" of abolition. Distilling a question pervading the majority of the conference papers, Roquinaldo Ferreira pondered how an integrated explanatory model of abolition at the intersection of subaltern agency and imperial and diplomatic hegemony would look like. How important were international currents to local developments, and were incidental occurrences of slave rebellion part of a global abolition struggle? Finally, how embedded were abolitionist struggles in broader questions of federalism and state-building, and vice-versa?

At a more fundamental level lies the question of periodization. Was there one "age of abolition" or were there several, and is the Age of Abolition over? How do we account for the global age of abolition: As an international response to the rise of second slavery; as a set of transnational developments unleashed by revolution, more specifically the Haitian Revolution; or as an age grappling with the emergence and growth of free labor? As each of these possible conceptualizations entails a different periodization, we may be inclined to think of several ages of abolition, and differentiate them both spatially and thematically: as abolition moved, so too, did the strategies and ideologies of abolitionists or agents of abolition. Thinking about these developments also calls for greater attention to trans- and non-Atlantic developments in a literature still greatly shaped by the Atlantic perspective. African, Asian, Pacific, and East European developments contributed to global abolition in no smaller degree than Atlantic processes, even if the vast scope, brutality, and visibility of the transatlantic slave trade overshadowed these alternative theaters in the minds of abolitionists and the global public. By realizing that globalizing the discussion of abolition goes hand in hand with positioning abolition within the history of globalization, scholars can develop new conceptual frameworks for defining and operationalizing the "global age of abolition" as an integral component in the historical formation of our world. 